\title{
How is Students' Creative Thinking Skills? An Ethnoscience Learning Implementation
}

\author{
Ahmad Khoiri*1, Nulngafan ${ }^{2}$, Widha Sunarno ${ }^{3}$, Sajidan ${ }^{4}$ \\ ${ }^{1}$ Physics Education Department, Universitas Sains Al Qur'an, Jl. K.H Hasyim Asyari Km 03 Mojotengah \\ Wonosobo 56351, Central Java, Indonesia \\ ${ }^{2}$ Informatics Engineering Department, Universitas Sains Al Qur'an, Central Java, Indonesia \\ ${ }^{3}$ Physics Education Department, Universitas Sebelas Maret Surakarta, Indonesia \\ ${ }^{4}$ Biology Education Department, Universitas Sebelas Maret Surakarta, Indonesia
}

*Corresponding address: akhoiri@unsiq.ac.id.

\begin{tabular}{|c|c|}
\hline Article Info & ABSTRACT \\
\hline Article history: & The objectives of this research is to know the characteristics of ethnoscience \\
\hline $\begin{array}{l}\text { Received: Juli } 7^{\text {th }}, 2019 \\
\text { Accepted: October } 22^{\text {nd }}, 2019 \\
\text { Published: Oktober } 30^{\text {th }}, 2019\end{array}$ & $\begin{array}{l}\text { learning in developing creativity and testing its effect on students' creativity. } \\
\text { This type of research is a Quasi-experimental one-group pretest-posttest } \\
\text { design. A total of } 31 \text {-third year students from Physics Education study } \\
\text { programs were chosen as the sample of the research through a purposive }\end{array}$ \\
\hline $\begin{array}{l}\text { Keywords: } \\
\text { creativity thinking; } \\
\text { ethnoscience in physics; } \\
\text { revolution } 4.0 \text { era; }\end{array}$ & $\begin{array}{l}\text { Creative Thinking, creativity questionnaires, in-depth interviews, and } \\
\text { documentation. T-test with T-value test by LISREL } 8.8 \text { Second-order CFA } \\
\text { application was used to analyze the data. The results showed that the } \\
\text { ethnographic science learning model is a strategy for creating and designing } \\
\text { a learning environment that integrates community culture through } \\
\text { environmental studies. Based on the t-test, the indicator of creativity is } 4.47 \text {, } \\
\text { flexibility is } 5.22 \text {, originality is } 4.88 \text {, elaboration is } 5.96 \text {, and redefinition is } \\
6.24 \text {, with Ttable of } 1,97 \text {. It means that ethnoscience learning is effective in } \\
\text { increasing student creativity. It is recommended to reconstruct the original } \\
\text { science into scientific science to preserve the culture of society which is a } \\
\text { challenge in the era of industrial revolution } 4.0 \text {. }\end{array}$ \\
\hline
\end{tabular}

(C) 2019 Physics Education Department, UIN Raden Intan Lampung, Indonesia

\section{INTRODUCTION}

Sophisticated digitalization system seems to erode the rooted tradition in society (Peters \& Jandrić, 2017; Schröder, 2019). Information and technology have become the basis in human life (Alreemy, Chang, Walters, \& Wills, 2016; Rondan-Cataluña, Arenas-Gaitán, \& Ramírez-Correa, 2015). In this era, it is important to produce creative graduates, master the technology, and able to compete in the global era (Barry, 2016), yet, still upholds cultural traditions.

Science learning carried out so far is still very formal and cannot explore students' creative ideas (Chasanah, Khoiri, \& Nuroso,
2016; Rohmadi, 2018). Moreover, students as prospective educators must be able to understand learning models that can help them to understand the environment, traditions, culture, and apply the science concepts in the environment.

Offering to learn through the ethnographic approach is needed to provide teaching materials based on local potential oriented to the environment, so that it can provide information on the potential that exists in the area and can be developed into creative ideas (Khoiri, Syifa, \& Mubin, 2018; Khoiri \& Haryanto, 2018). Teaching materials with the ethnoscience approach 
can be used as a reference to equip students with knowledge and character that respects the local culture (Arlianovita, Setiawan, \& Sudibyo, 2015; Fitriani, 2016; Vitasurya, 2016).

Based on the results of previous studies, ethnographic-based learning can improve science process skills and student appreciation (Atmojo, 2012), learning achievement (Okwara \& Upu, 2017), and the ability to use scientific knowledge (science literacy) (Sudarmin, Mastur, \& Parmin, 2014). Through ethnoscience-based learning, individuals increasingly master the concepts of science in culture because they learn directly in the environment (Becker \& Park, 2011) so that the form of appreciation in the form of curiosity and attention to the traditions and culture of the community increases (Okwara \& Upu, 2017).

Ethnographic-based learning is still very rarely done in Indonesia, although there are, these studies still have not shown how much ethnoscience influences individual creative thinking abilities. This research offers knowledge about how much ethnoscience learning influences the ability to think creatively, and the processes of implementing ethnoscience in learning.

\section{METHODS}

This type of research is a quasiexperimental one-group pretest-posttest design. The study population was all students of Physics Education at the Universitas Sains Al-Qur'an (UNSIQ) Wonosobo, which consisted of 286 students. Through purposive sampling technique, 31 seventh-semester students who were taking Environmental Physics courses were selected.

The data collection method used was the TTCT (Torrance Test Creative Thinking). Creativity test was in the form of a description of Braak's theory, hydrostatic pressure, and expansion. In-depth interviews were conducted with Carica farmers and tobacco farmers. Interviews with Carica farmers were conducted to dig up information about the Carica fruit harvest time, and interviews with tobacco farmers were conducted to dig up information on processing tobacco waste. Documentation of the profile of the surrounding environment in the Dieng Plateau area to study the Braak's theory and student questionnaire responses to ethnics learning to determine the feasibility of learning.

The T-test analysis technique used was the Lisrel 8.8 Second-Order CFA application to find out the effectiveness of ethnoscience learning in increasing student creativity. The creativity indicators are presented in table 1.

Tabel 1. Indicators of creativity (Torrance, 1974)

\begin{tabular}{|c|c|c|}
\hline $\begin{array}{l}\text { Indicators of } \\
\text { Creativity }\end{array}$ & & Sub Indicator \\
\hline Fluency & & $\begin{array}{l}\text { Skills to spark ideas, answers, } \\
\text { problem solving } \\
\text { Skills to provide methods or } \\
\text { advice } \\
\text { The skill of thinking about } \\
\text { alternative answers }\end{array}$ \\
\hline Flexibility & & $\begin{array}{l}\text { Skills generate ideas, answers } \\
\text { or questions that vary } \\
\text { Skills in seeing problems } \\
\text { from different points of view } \\
\text { The skill of looking for many } \\
\text { different alternatives }\end{array}$ \\
\hline Originality & & $\begin{array}{l}\text { Ability to give birth to new } \\
\text { and unique expressions } \\
\text { Thinking about an unusual } \\
\text { method } \\
\text { Ability to combine }\end{array}$ \\
\hline Elaboration & & $\begin{array}{l}\text { The skill of developing ideas } \\
\text { Skills detailing an object }\end{array}$ \\
\hline Redefinition & & $\begin{array}{l}\text { The skill to redefine creative } \\
\text { products that are not yet } \\
\text { perfect }\end{array}$ \\
\hline
\end{tabular}

The entire research process is illustrated in the following chart Figure 1, 


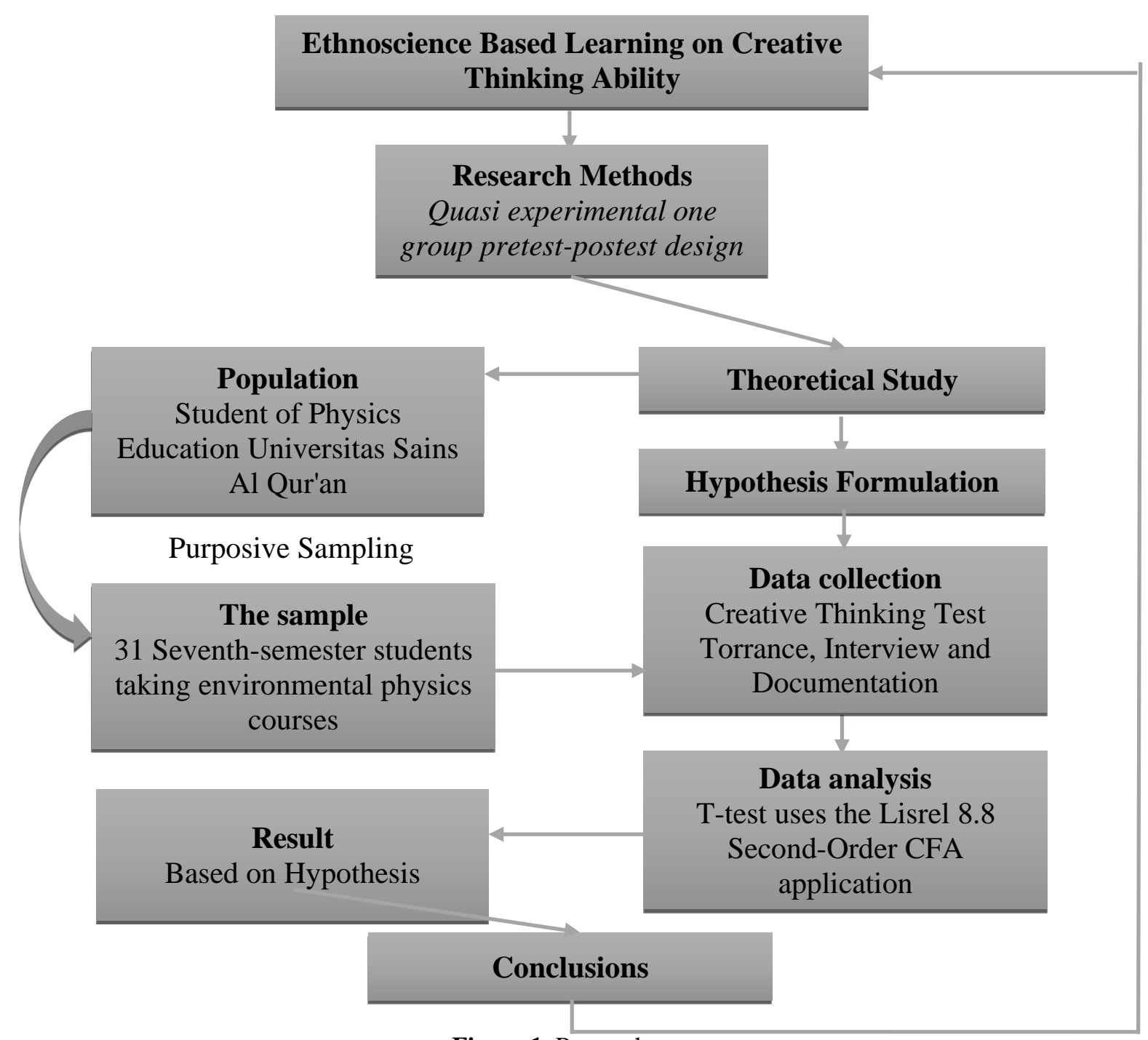

Figure 1. Research process

\section{RESULTS AND DISCUSSION}

Ethnoscience learning always links learning with the culture of the local community. In this study, learning is associated with the culture and traditions of the people of Wonosobo Regency, Central Java Province. Learning resources studied in learning environmental physics are presented in table 2.

Table 2. Ethnoscience Learning Model

\begin{tabular}{ccc}
\hline $\begin{array}{c}\text { Ethnoscience } \\
\text { Source }\end{array}$ & Concept & Variable \\
\hline Carica Plants & Braak' Theory & Creativity \\
Tobacco & Hydrostatic & Peer Service \\
Extract & Pressure & \\
Banana Skin & Temperature & \\
Flour & & \\
\hline
\end{tabular}

\section{Analysis of the Dieng Plateau Height on Braak' Theory.}

Carica plants are part of the local potential of the Wonosobo district which cannot live in other areas. In this research, one form of creativity carried out is to formulate problem-solving. Students gave a temporary suspicion that the Carica Plant could only grow in Wonosobo because of differences in height and special characteristics in the Dieng plateau. The learning process is carried out by measuring the temperature using a thermometer and experiments on Carica plants to analyze the height of the Dieng plateau developed in environmental physics learning (Diki, 2014). 
The smooth thinking of students can be seen from the process of observing temperatures in the Dieng plateau with three different locations to identify whether there are differences in temperature that cause Carica plants to grow. Because Carica plants only grow in Dieng locations (Minarno, 2015). This has become an important factor in encouraging students to find reasons for the phenomenon so that students' creative thinking and positive attitudes towards the environment can be cultivated (Kutlu \& Gökdere, 2015; Şener, Türk, \& Taş, 2015). In addition to solving it, students are also required to study the problem through the study of Braak's theory (Fitria \& Wisudawati, 2018).

The height of a place on the surface of the earth affects the high and low temperatures and pressures of an area. the higher an area, the lower the air temperature will be. each land elevation of $100 \mathrm{~m}$ will decrease by $0.61{ }^{\circ} \mathrm{C}$ but for dry air, the air temperature drops $100{ }^{\circ} \mathrm{C}$.

Braak' Theory: t: $26,3^{\circ} \mathrm{C}-\frac{0,61^{\circ} \mathrm{C}(1379)}{100}(1)$

Dieng is a plateau area located on the island of Java with a land height reaching 2400 meters above sea level. Fruitproducing plants that can only grow in its low-temperature areas, namely Carica fruit (Caricapubescens) (Minarno, 2015). Carica plant is endemic because it can only grow at an altitude of 1500-3000 m above sea level. Figure 2 shows the Carica plant and the Dieng plateau.

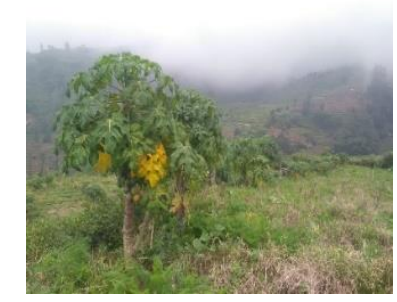

(b)

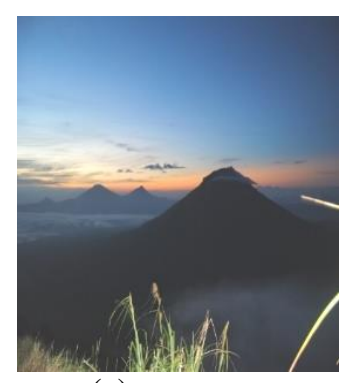

(a)
Figure 1. The Carica Plant

Figure 2a shows the height of the Dieng Plateau, and Figure $2 b$ is a Carica plant that can bear fruit. Analysis of the research area at an altitude of about 1300-2400 above sea level. The Dieng region represents a height approaching 2000 meters, the parallel region represents a height approaching 1700 meters, the Garung area represents a height of around 1300 meters, so that it can be systematically calculated:

Garung temperature

$$
\begin{aligned}
& : 28,5{ }^{\circ} \mathrm{C}-\frac{0,61^{\circ} \mathrm{C}(1019)}{100} \\
& : 28,5{ }^{\circ} \mathrm{C}-6,2{ }^{\circ} \mathrm{C} \\
& : 22,3^{\circ} \mathrm{C}
\end{aligned}
$$

Kejajar temperature

$$
\begin{aligned}
& : 28,5^{\circ} \mathrm{C}-\frac{0,61^{\circ} \mathrm{C}(1379)}{100} \\
& : 28,5{ }^{\circ} \mathrm{C}-8,4^{\circ} \mathrm{C} \\
& : 20,1^{\circ} \mathrm{C}
\end{aligned}
$$

Dieng temperature

$$
\begin{aligned}
& : 28,5{ }^{\circ} \mathrm{C}-\frac{0,61^{\circ} \mathrm{C}(2306)}{100} \\
& : 28,5^{\circ} \mathrm{C}-14,5^{\circ} \mathrm{C} \\
& : 14,0^{\circ} \mathrm{C}
\end{aligned}
$$

The height of the Garung region which is 1019 above sea level produces a temperature of $22.3^{\circ} \mathrm{C}$, the Aligned area of 1379 above sea level produces a temperature of $20.1^{\circ} \mathrm{C}$ and the Dieng region of 2306 masl produces a temperature of $14.0^{\circ} \mathrm{C}$, the higher the region, the lower the temperature environment around it. Carica trees only live in the Dieng region. Temperature is a measure of how hot or cold a system is. The higher a plateau, the lower the air pressure, therefore the density of air is also smaller. If the air density is getting smaller, the number of airborne particles will be less unified in volume. Therefore the higher the terrain, the lower the temperature.

Learning to foster student creativity has three principles: diversity and clear teaching strategies, an emphasis on developing student creativity and developing studentfocused teaching. (Amabile, 1997; Ann Coughlan, 2007; Guilford, 1950; Simonton, 2012). The improvement of students' creative thinking skills is in line with the research conducted (Fatimah Nur, Sri Susilogati Sumarti, 2017), so that (Piirto, 2011) reinforces that ethnics learning 
resources by exploring learning resources in the environment will bring up creative ideas.

\section{Making Tobacco Extract Based on the} Concept of Hydrostatic Pressure.

Students performed practical activities in making tobacco stem extract and used it as a sample of liquid to study hydrostatic pressure.

Tobacco is a raw material from the manufacture of cigarettes which is very popular in Indonesia and can also live in the Wonosobo area. Students can learn the concept of hydrostatic pressure used in liquid substances from tobacco pesticide extracts. Liquid pesticides at any point located on a horizontal plane in a container of a type of liquid in the same state are the same.

Analysis of liquid results from tobacco stem extracts was investigated whether it could provide information to students about the same or different hydrostatic pressures when compared with other liquids. Presented the process of making tobacco extract in figure 3 .

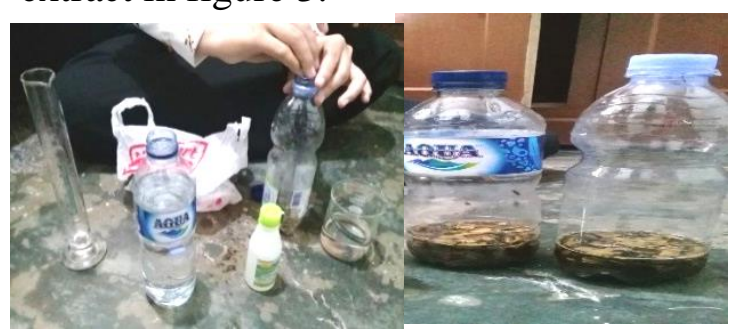

Figure 2. Tobacco extract pesticide using hydrostatic pressure

Figure 3 Student activities making liquid extracts from tobacco. Pressure applied to fluids based on Pascal's Law systematically formulated $\mathrm{P}=\rho \mathrm{gh}$ produced in tobacco extracts for pesticides of $0.95 \mathrm{~Pa}$ and in the water of $1 \mathrm{~Pa}$.

\section{Making Banana Flour Based on the Expansion Concept.}

Environmental physics activity through analysis of banana peel flour in analyzing the concept of expansion. Banana producers are spread throughout the Wonosobo district. Banana plantation areas have the potential for unproductive waste
(Nafingah \& Irhandayaningsih, 2011). How do students have creativity in processing banana peels into flour?

Before the study was conducted, banana peel flour was made in the following steps:

- Banana peels collected;

- Banana peels are washed clean and cut into small pieces;

- Pieces of banana peels are dried in the sun to dry; (Figure 4)

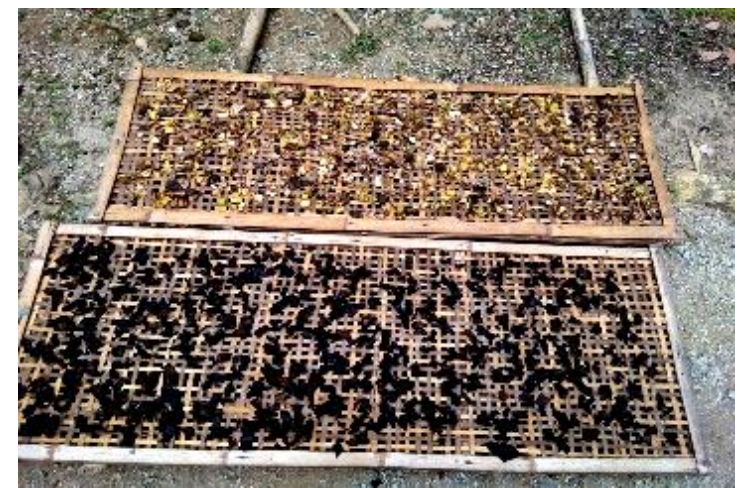

Figure 4. The banana skin drying process

- After drying, pieces of banana peel are mashed using a blender;

- Finished results are sifted to get fine flour.

After the process had been carried out, an analysis of the expansion of the processed banana skin flour is presented in figure 5 .

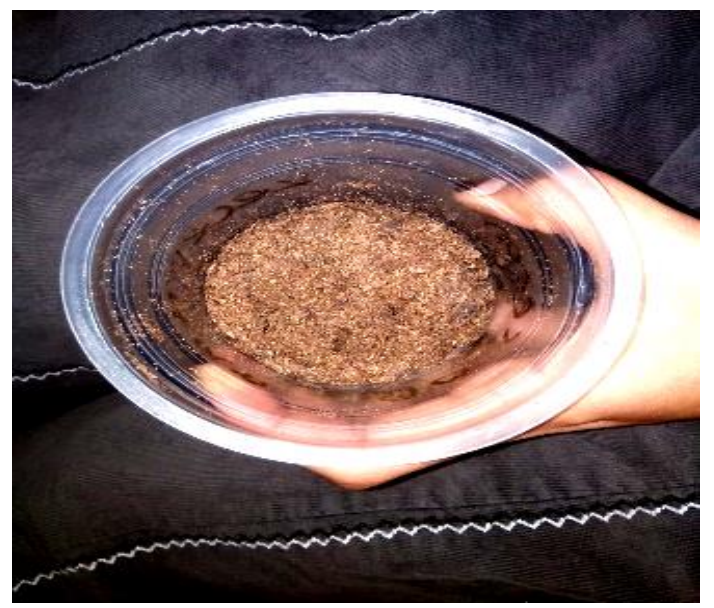

Figure 5. Banana mash

Figure 5 shows banana peel flour compared to wheat flour. The results showed that the fried banana flour dough did not expand compared to the fried flour 
dough. The results were the same because the banana peels are sticky, so, when there is a change in temperature, the dough does not have enough energy to expand.

Figure 6 and figure 7 show the banana skin flour before and after frying to compare the extent of the two. The concept of expansion if there are differences in volume, breadth, and length, but in learning activities, it is not.

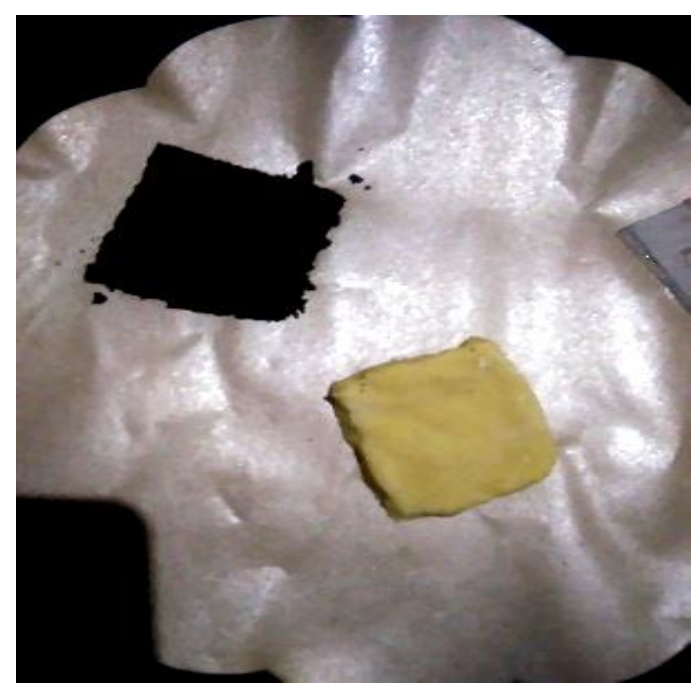

Figure 6. Dough before frying

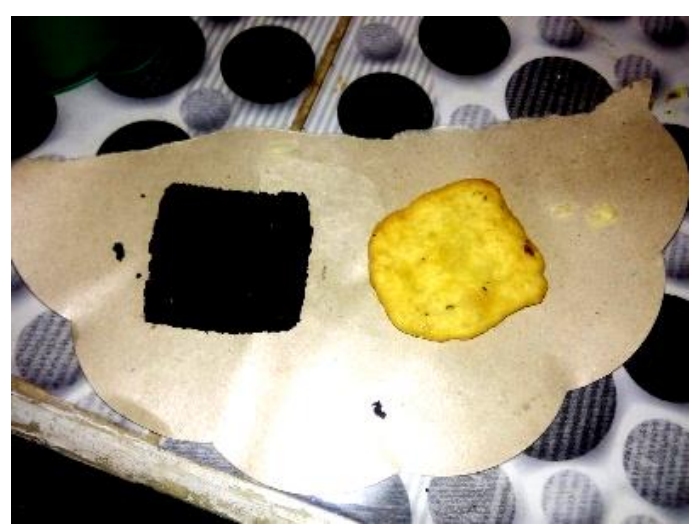

Figure 7. Dough after frying

Next, based on Figure 7, the viscosity of the banana peel and flour was analyzed by comparing the time of the two solutions flowing from one place to another. The result is that wheat flour requires a longer time compared to banana peel flour so that the viscosity of banana peel flour is smaller than wheat flour.

Based on student learning activities on the environment that creativity is influenced by the perception of environmental conditions by collecting information, collecting data, solving problems, bringing up new ideas in the environment so that it can ultimately foster creativity (Ibrahim \& Irawan, 2015).

Creativity with the ethnoscience approach will be more effective than other learning because it can utilize all forms of values in society, traditions, culture, and types of regional potential that can provide many opportunities given the very complex environmental problems.

Ethnoscience trains students to think creatively through ideas to solve environmental problems as a source of information because Ethnoscience is a form of strategy for creating and designing a learning environment that integrates community culture (Khoiri, Kahar, \& Indrawati, 2018).

\section{Test the Significance of Student Creativity Through Ethnoscience Learning Model.}

Based on ethnics' science learning activities in environmental physics, students' creativity was further identified through each indicator presented in the output of the CFA Lisrel Second-Order application. The questions on creativity consist of 20 questions that represent five indicators of creativity, namely: Fluency (X1), Flexibility (X2), Originality (X3), Elaboration (X4), and Redefinition (X5).

Each indicator is formulated in two items. After analyzing the 31 respondents presented in the table of criteria goodness of fit index presented in table 3 .

Tabel 3. The goodness of Fit Index

\begin{tabular}{llll}
\hline $\begin{array}{l}\text { The goodness of fit } \\
\text { Index }\end{array}$ & $\begin{array}{l}\text { Cut off } \\
\text { value }\end{array}$ & Results & Inf \\
\hline $2 \chi$ - Chi-square & - & 40,28 & \\
Probability & $\geq 0,05$ & 0,09 & Fit \\
RMSEA & $\leq 0,08$ & 0,052 & Fit \\
Normed Fit Index & $\geq 0,90$ & 0,96 & Fit \\
(NFI) = 0.89 & & & \\
Non-Normed Fit & $\geq 0,90$ & 0,94 & Fit \\
Index (NNFI) & & &
\end{tabular}




\begin{tabular}{llll}
\hline $\begin{array}{l}\text { The goodness of fit } \\
\text { Index }\end{array}$ & $\begin{array}{l}\text { Cut off } \\
\text { value }\end{array}$ & Results & Inf \\
\hline $\begin{array}{l}\text { Comparative Fit } \\
\begin{array}{l}\text { Index (CFI) } \\
\text { Incremental Fit Index } \\
\text { (IFI) }\end{array}\end{array}$ & $\geq 0,90$ & 0,96 & Fit \\
$\begin{array}{l}\text { Relative Fit Index } \\
\text { (RFI) }\end{array}$ & $\geq 0,90$ & 0,96 & Fit \\
\hline
\end{tabular}

Based on Table 3, the information of goodness of fit index meets the criteria, then presented in the path diagram in figures 8 and 9.

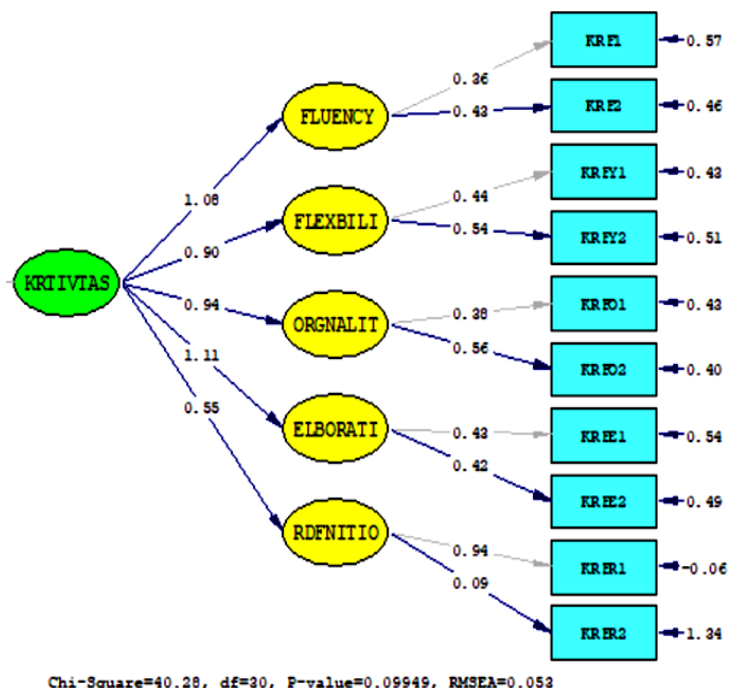

Figure 8. CFA second-order estimates results

Figure 8 shows the estimated value of the creativity indicator as a criterion for fulfilling the criteria for each creativity indicator (X1, X2, X3, X4, and X5).

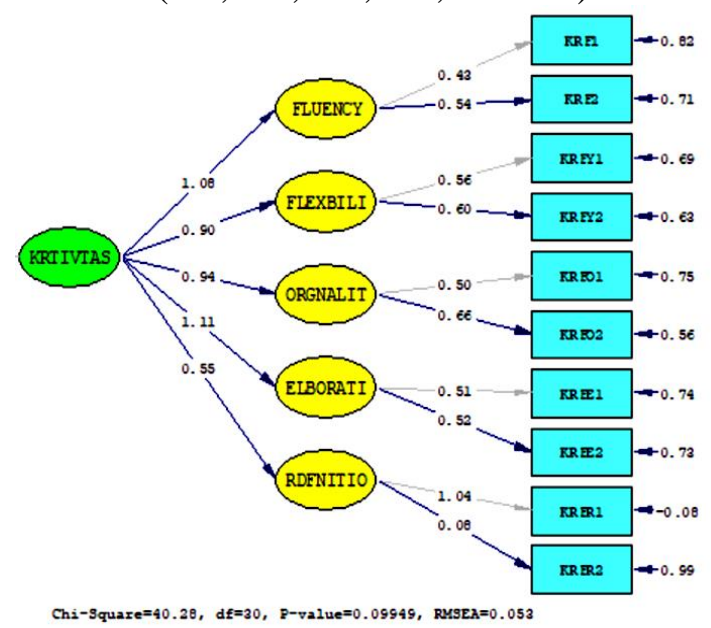

Figure 9. The loading factor value of each indicator in the CFA Standarazied Solution Second-Order display.
Figure 9 loading factor values greater than 0.3 for each instrument that builds the indicators Fluency (X1), Flexibility (X2), Originality (X3), Elaboration (X4) and Redefinition (X5). The indicator is only one instrument that is not valid for measuring creativity, namely item 10 of KR. ER2 code because the loading factor results are less than $0.3 \quad(0.06<0.3)$, which is the Redefinition indicator.

Furthermore, to find out the effectiveness of the ethnics learning model in improving student creativity is presented in figure 10 .



Figure 10. CFA second-Order T-value

Figure 10 shows the calculated value for each item which is $4.47 ; 5,22 ; 4.88 ; 5.96$; 6.24 in a row. These values are greater than the value of the table at the significance level $\alpha=0.05$ and free degree 30 (n-1) of 1.97. This means that there is a significant influence between each item on creativity because the overall result of $t_{\text {count }}$ is more than $\mathrm{t}_{\text {table }} 1.97$ ( $\left.\mathrm{t}_{\text {count }} \geq \mathrm{t}_{\text {table }}\right)$.

Through Carica plants that only live in the Dieng highlands, the tobacco plant' stems to extract pesticides with the concept of hydrostatic pressure, and the banana peel flour in expansion theory, students' creativity could be trained. Scientific activities are used as formal science for learning sources of ethnoscience by exploring local potential in Wonosobo Regency, so that learning of ethics in the era 
of the industrial revolution is effective in increasing student creativity based on the Indonesian National Curriculum Framework (INCF or KKNI) through knowledge of the environment, attitudes to overcome environmental problems.

Discovery-oriented learning raises many alternative answers to problem-solving on indicators of creativity. Complex environmental problems provide opportunities for students to find creative solutions. Strengthened by (Khoiri \& Haryanto, 2018) that local potential which is part of the ethnoscience approach in learning is made a concrete learning resource for analyzing the environment making students more active and appreciating the potential of their regions. Next (Utami, 2016). Local wisdom part of ethnoscience is the result of the cultural heritage of the ancestors and can improve students' understanding of concepts aided by the STEM-A approach. Ethnoscience learning has been proven to be able to develop original knowledge in a community studied through formal science as a learning study (Sudarmin, 2014).

Other research also shows that there are differences in the results of the ability to solve physics problems between causal models based on ethnoscience that is higher than modern science, the reason that culture inherent in the community provides a more real reference to learning physics resources in understanding science problems. (Supriyadi, Haeruddin, \& Nurjannah, 2016). This is also corroborated by (Fitria \& Wisudawati, 2018) which examines ethnographic-related teaching materials that can improve students' scientific literacy through the introduction of Yogyakarta culture or customs such as the variety of Jogja Batik, Wayang Kulit and Mount Merapi which are used as learning resources for turning original science into science studies by utilizing regional culture in increasing cognitive, affective abilities and psychomotor.
Although proven to be good for application, ethnographic-based learning is still very rarely done in Indonesia. Some of what has been done as mentioned previously has not yet shown how much ethnoscience influences individual creative thinking abilities. This research offers knowledge about how much ethnoscience learning influences the ability to think creatively and the processes of implementing ethnoscience in learning.

Based on the description of the ethnocentric environmental activities, the students are able to learn more real physics concepts in the culture of society by reconstructing original science into scientific science through creative ideas to find solutions to environmental problems, as well as introducing the culture and traditions of the community that must be maintained and preserved by generations for generations continuously.

\section{CONCLUSION AND SUGGESTION Conclusion}

Based on the results of the study, ethnoscience learning proved to have a significant effect on students' creative thinking abilities. Ethnoscience learning is implemented in the form of strategies to create and design learning that integrates community culture so that students can explore creative ideas through environmental learning activities.

\section{Suggestion}

For further researchers, it is better to determine what concepts will be learned considering the study of ethnoscience in the community is very broad.

\section{ACKNOWLEDGMENT}

Thank you to Kemenristekdikti for the assistance of the PDP grant that was given so that the research activities went smoothly. Thanks to the Universitas Sains Al-Qur'an Wonosobo for the permission given in conducting research. 


\section{AUTHOR CONTRIBUTIONS}

AK conceptualizes and designs NA lessons collecting and analyzing data. WS outlines the results. SD outlines discussion and editing.

\section{REFERENCES}

Alreemy, Z., Chang, V., Walters, R., \& Wills, G. (2016). Critical Success Factors (CSFs) for Information Technology Governance (ITG). International Journal of Information Management, 36(6), 907-916. https://doi.org/10.1016/j.ijinfomgt.2016 .05 .017

Amabile. (1997). Motivating Creativity in Organizations: On Doing What You Love and Loving what you do. California Management Review, 40(I), 39-59.

Coughlan, A. (2007). Learning to Learn: Creative Thinking and Critical Thinking. DCU Student Learning Resources.

Arlianovita, D., Setiawan, B., \& Sudibyo, E. (2015). Pendekatan Etnosains dalam Proses Pembuatan Tempe terhadap Kemampuan Literasi Sains. Seminar Nasional Fisika dan Pembelajarannya(pp.101-107).

Atmojo, S. E. (2012). Profil Keterampilan Proses Sains dan Apresiasi Siswa terhadap Profesi Pengrajin Tempe dalam Pembelajaran IPA Berpendekatan Etnosains. Jurnal Pendidikan IPA Indonesia, 1(2), 115122.

https://doi.org/10.15294/jpii.v1i2.2128

Barry. (2016). Beverage engineers: Creative international STEM project. International Journal of Humanities and Social Sciences, 8(4), 18-28.

Becker, K., \& Park, K. (2011). Effects of Integrative Approaches Among Science, Technology, Engineering, And Mathematics ( STEM ) Subjects on Students' Learning: A Preliminary Meta-Analysis. Journal of STEM Education, 12(5).
Chasanah, A. R. U., Khoiri, N., \& Nuroso, H. (2016). Efektivitas Model ProjectBased Learning terhadap Keterampilan Proses Sains dan Kemampuan Berpikir Kreatif Siswa pada Pokok Bahasan Kalor Kelas X SMAN 1 Wonosegoro Tahun Pelajaran 2014/2015. Jurnal Penelitian Pembelajaran Fisika, 7(April), 19-24. Retrieved from http://e-

jurnal.upgrismg.ac.id/index.php/JP2F

Diki, D. (2014). Creativity for Learning Biology in Higher Education. Lux, 3(1), $1-12$. https://doi.org/10.5642/lux.201303.03

Fatimah, N., Sumarti, S., S., Wardani, S. (2017). Pengaruh Student Facilitator and Explaining dengan Roda Impian Terhadap Hasil Belajar Siswa. Chemistry in Education, 6(2), 8-14.

Fitria, M., \& Wisudawati, A. W. (2018). The Development of EthnoscienceBased Chemical Enrichment Book as a Science Literacy. International Journal of Chemistry Education Research, 2(1), $50-59$.

https://doi.org/10.20885/ijcer.vol2.iss1. art8

Fitriani, N. L. F. (2016). Physics Education based Ethnoscience: Literature Review. International Conference on Mathematics, Science, and Education 2016 (ICMSE 2016), 2016(Icmse), 3134.

Guilford, J. P. (1950). Creativity. American Psychologist, 5, 444-454.

Ibrahim, M., \& Irawan, A. (2015). Effectivity of Peer Tutoring Learning to Increase Mathematical. International Journal of Education and Research, $3(1)$, 613-628. https://doi.org/10.1038/NPHOTON.20 12.146

Khoiri, A., Kahar, M. S., \& Indrawati, R. T. (2018). Ethnoscience Approach in Cooperative Academic Education Programs (COOP). Journal of Physics: Conference Series, 1114(1). https://doi.org/10.1088/1742- 
6596/1114/1/012018

Khoiri, A, \& Haryanto, S. (2018). The 21St Century Science Skills Profile Based Local Wisdom Education (Tourist Attractions and Typical Foods in Regency of Wonosobo). Jurnal Penelitian dan Pengabdian Kepada Masyarakat UNSIQ, 5(3), 361-371. https://doi.org/10.32699/ppkm.v5i3.48 5

Khoiri, Ahmad, Syifa, A., \& Mubin, N. (2018). Potential Local Physics Based Learning of Jepara District to Improve Science Process Skills and Students Entrepreneurship. Formatif: Jurnal Ilmiah Pendidikan MIPA, 8(1), 57-68. https://doi.org/10.30998/formatif.v8i1. 2365

Kutlu, N., \& Gökdere, M. (2015). The Effect of Purdue Model Based Science Teaching on Creative Thinking. International Journal of Education and Research, 3(3), 589-599.

Minarno, E. B. (2015). Skrining Fitokimia dan Kandungan Total Flavanoid pada Buah Carica pubescens Lenne \& K. Koch di Kawasan Bromo, Cangar dan Dataran Tinggi Dieng. El-Hayah, 5(2), 73-82.

https://doi.org/10.4269/ajtmh.1986.35. 167

Nafingah, L., Irhandayaningsih, A. (2017). Implementasi Program Perpuseru dan Peranannya dalam Kejajar Kabupaten Wonosobo. Jurnal Ilmu Perpustakaan, 6(3), 101-110.

Okwara, O. K., \& Upu, F. T. (2017). Effect of Ethnoscience Instructional Approach on Students Achievement and Interest in Upper Basic Science and Technology in Benue State Nigeria. International Journal of Scientific Research in Education, 10(1), 69-78.

Peters, M. A., \& Jandrić, P. (2017). Dewey's Democracy and Education in the Age of Digital Reason: the Global, Ecological and Digital Turns. Open Review of Educational Research, 4(1), 205-218. https://doi.org/10.1080/23265507.2017. 1395290

Piirto, J. (2011). Creativity for 21st. In Sense Publishers.

Rohmadi, M. (2018). Strategi dan Inovasi dalam Pembelajaran Bahasa dan Sastra Indonesia di Era Industri 4.0. Pertemuan Ilmiah Bahasa Dan Sastra Indonesia, 21, 27-40.

Rondan-Cataluña, F. J., Arenas-Gaitán, J., \& Ramírez-Correa, P. E. (2015). A Comparison of the Different Versions of Popular Technology Acceptance Models a Non-linear Perspective. Kybernetes, 44(5), 788-805. https://doi.org/10.1108/K-09-20140184

Schröder, T. (2019). A Regional Approach for the Development of TVET Systems in the Light of the 4th Industrial Revolution: the Regional Association of Vocational and Technical Education in Asia. International Journal of Training Research, 17(sup1), 83-95. https://doi.org/10.1080/14480220.2019. 1629728

Şener, N., Türk, C., \& Taş, E. (2015). Improving Science Attitude and Creative Thinking Through Science Education Project: A Design, Implementation and Assessment. Journal of Education and Training Studies, 3(4), 57-67. https://doi.org/10.11114/jets.v3i4.771

Simonton, D. K. (2012). Taking the U.S. Patent Office Criteria Seriously: A Quantitative Three-Criterion Creativity Definition and Its Implications. Creativity Research Journal, 24(2-3), 97-106.

https://doi.org/10.1080/10400419.2012. 676974

Sudarmin, S., Mastur, Z., \& Parmin, P. (2014). Merekontruksi Pengetahuan Sains Ilmiah. Jurnal Penelitian Pendidikan, 31, 55-62.

Supriyadi, S., Haeruddin, H., \& Nurjannah, N. (2016). Peningkatan Kemampuan Memecahkan Masalah Antara Model 
Penalaran Kausal Berbasis Etnosains dan Sains Modern. Jurnal Riset dan Kajian Pendidikan Fisika, 3(2), 35. https://doi.org/10.12928/jrkpf.v3i2.514 2

Torrance, E. P. (1974). Norm-Technical Manual Torrance Test of Creative Thinking, Verbal Test, Form A and B. Figural Test, Form A and B,. Personal Press Inc, Lexing-Ton, Massachusetts.

Utami. (2016). Cordierite Ceramics Synthesized Based on Husk Silica as Electrical Isolator Material. Jurnal
Ilmiah Pendidikan Fisika Al-Biruni, 5(2), 161-172. https://doi.org/10.24042/jipf

Vitasurya, V. R. (2016). Local Wisdom for Sustainable Development of Rural Tourism, Case on Kalibiru and Lopati Village, Province of Daerah Istimewa Yogyakarta. Procedia - Social and Behavioral Sciences, 216(October 2015), 97-108. https://doi.org/10.1016/j.sbspro.2015.1 2.014 